\title{
The Impact of Leadership Style, Work Environment and Job Satisfaction on Employee Performance
}

\author{
Nurul Qomariah $^{1}$, Deny Friyanti ${ }^{2}$, Eko Budisatoto ${ }^{3}$, Masram $^{4}$, Mu'ah $^{5}$ \\ ${ }^{123}$ Universitas Muhammadiyah Jember, Jalan Karimata 49 Jember 68121 Jawa Timur Indonesia. \\ ${ }^{45}$ STIE KH Ahmad Dahlan Lamongan.
}

Orchid id: 0000-0001-8662-8904

\begin{abstract}
This study aims to: test and analyze the influence of leadership style, work environment, and job satisfaction on employee performance in employees of BPKAD (Regional Financial and Asset Management Agency) Bondowoso Regency. The population in this study were all employees of BPKAD in Bondowoso Regency, totaling 61 civil servants. The entire population is sampled in this study, so it is also called census research. Validity and reliability tests are used to test the measurement tools in the form of questionnaires. The analysis tool uses Partial Least Square (PLS). The results of hypothesis testing indicate that leadership style has a significant effect on employee performance. Work environment has a significant effect on employee performance. Job satisfaction has a significant effect on employee performance.
\end{abstract}

Keywords: leadership style; work environment; job satisfaction; employee performance.

\section{INTRODUCTION}

In-Law Number 32 article 25 of 2004 it is explained that each regional head has duties and authorities, among others: 1) to lead the region based on policies determined by the DPRD; 2) submit a Perda plan; 3) Establishing Regional Regulations that have been agreed with the DPRD; 4) compile and submit a draft Perda on APBD to the DPRD to be discussed and determined together; 5) work towards the implementation of regional obligations; 6) represent the area inside / outside the court and can appoint a legal representative to represent it in accordance with statutory regulations; 7) carry out duties and authorities in accordance with statutory regulations. The most important part of the task of local government is to provide services to the needs of the community they are responsible for. In order for services to the community to run as expected, a division of tasks was held with the formation of a Regional Government Work Unit (SKPD).

Services to the community must continue to be improved often with increasing community needs. Service to the community can run well if the personnel in it continue to be committed to improving its performance. According to Government Regulation Number 46 of 2011 the assessment of Civil Servants' work performance can be measured by assessing Employee Work Targets (SKP) and work behavior. Employee Work Targets, hereinafter abbreviated as SKP are work plans and targets to be achieved by a civil servant. Work behavior is any behavior, attitude or action taken by a civil servant or does not do something that should be done by statutory provisions. The assessment of employee work behavior includes five aspects, namely service orientation, integrity, commitment, discipline, cooperation, and leadership. From the results of the assessment of employee work behavior and then grouped based on a certain predicate that is very good (91-up), good (76-90), enough (61-75), less (51-60) and (50 and below) bad. A good employee will try to increase the value of his SKP. This SKP value illustrates the performance of a civil servant. Increasing competition in the current 4.0 industry era, requires government and private organizations to continue to improve the best service for service users. Superior service is the key to the success of an organization, both government and private organizations. Superior service will be achieved if the performance of the organization goes well. Good organizational performance is inseparable from the performance of good employees as well.

Performance is a result of work achieved by a person in carrying out the tasks assigned to him based on skill, experience, and sincerity and time(Hasibuan, 2013). Performance is basically what employees do or don't do (Davis $\&$ Newstorm, 2008). Performance is the responsibility of every individual for work, helping to define performance expectations, working for a framework for supervisors and workers to communicate with each other (Hariandja, 2007). Many factors can improve employee performance. Several factors are allegedly able to influence employee performance, including leadership style, work environment, and job satisfaction.

Leadership plays a very important role in an organization. Experts in the field of organization generally put forward their understanding of leadership. Leadership is defined in terms of individual characteristics, habits, ways of influencing others, interactions, positions in administration, and perceptions of legitimate influence. Leadership style, where the leadership style is the norm of behavior used by someone when the person is trying to influence the behavior of others or subordinates (Samsudin, 2006). Leadership style is the style of a leader in controlling his organization to achieve organizational goals (Azhad et al., 2015). Leadership is the way a leader influences the behavior of subordinates, so they are willing to work together and work productively to achieve organizational goals (Hasibuan, 2013). Leadership style is behavior and strategy, as 
a result of a combination of philosophy, skills, traits, attitudes that are often applied by a leader when he tries to influence the performance of his subordinates (Nawawi, 2008).

The next factor that can also improve performance is the environment in which employees work. The work environment is everything that is around workers and which can affect themselves in carrying out the tasks that are charged, for example, cleanliness, music, lighting, and others (Hasibuan, 2013). The work environment is the overall tools and materials faced, the surrounding environment in which a person works, his work methods, and his work arrangements both as individuals and as a group (Sedarmayati, 2011). A factor that can also improve performance is an employee's satisfaction. Employees who are satisfied working in an organization will perform well (Mu'ah, 2002). An employee will feel comfortable and high loyalty to the company if he gets job satisfaction by what is desired (Robbins, 2011). Job satisfaction is an emotional attitude that is fun and loves work. This attitude is reflected by work morale, discipline, and work performance. Job satisfaction is enjoyed at work, outside of work, and a combination of the two (Hasibuan, 2013).

Regional Financial and Asset Management Agency (BPKAD) of Bondowoso Regency. BPKAD is a government agency that was formed based on Bondowoso Regency Regulation Number 7 the Year 2016. BPKAD is also regulated based on Bondowoso Regency Regulation Number 79 the Year 2016 concerning Position, Organizational Structure, Duties and Functions and Work Procedures of the Financial and Asset
Management Agency of Bondowoso Regency. BPKAD of Bondowoso Regency as a technical institution of regional financial management is responsible for creating a regional financial management system that is synergized and integrated with all Bondowoso Regency Regional Work Units (SKPD) and is guided by the principles of effective, efficient, transparent and accountable financial management. This is in accordance with Permendagri No 13 of 2006, Permendagri No 59 of 2008 and Government Regulation number 58 of 2005 concerning regional financial management. This BPKAD carries out the mandatory functions of regional autonomy, general government, regional financial administration, regional apparatus, staffing, and coding. In addition, BPKAD Bondowoso Regency is responsible for the management of regional assets in order to improve the quality of asset data that supports the regional balance sheet. In carrying out its tasks, BPKAD is also demanded to provide the best service to the people who need services from BPKAD.

BPKAD performance achievements which are the responsibility of carrying out its main tasks and functions, as well as the authority to manage resources during 2018 based on measuring performance achievements against the performance targets set in the 2018 Performance Agreement (PK). This is an elaboration of the 2014-2018 RPJMD and target Plans Work (Renja) 2018. The performance achievements of the Regional Financial and Asset Management Agency until 2018 can be summarized in table 1.

Table 1: BPKAD Performance Achievements in 2018

\begin{tabular}{|c|c|c|c|c|c|c|}
\hline No. & $\begin{array}{l}\text { Results } \\
\text { Indicator }\end{array}$ & $\begin{array}{l}\text { Formula } \\
\text { Indicator }\end{array}$ & $\begin{array}{l}\text { Target } \\
\text { On } 2018\end{array}$ & $\begin{array}{l}\text { Realization } \\
\text { On } 2018\end{array}$ & $\begin{array}{l}\text { Achievements } \\
\text { The performance }\end{array}$ & Value \\
\hline 1 & $\begin{array}{l}\text { Percentage of OPD that } \\
\text { compiles the financial } \\
\text { statements }\end{array}$ & $\begin{array}{c}\sum \text { OPD which compiles } \\
\text { financial statements } \\
\sum \text { OPD }\end{array}$ & $100 \%$ & $100 \%$ & $100 \%$ & VS \\
\hline 2 & $\begin{array}{l}\text { Percentage of OPD } \\
\text { compiling RKA on time }\end{array}$ & $\begin{array}{l}\sum \text { OPD which compiles } \\
\text { RKA on time } \\
\sum \text { OPD }\end{array}$ & $100 \%$ & $100 \%$ & $100 \%$ & VS \\
\hline 3 & $\begin{array}{l}\text { Percentage of absorption of } \\
\text { APBD budget }\end{array}$ & $\frac{\sum \text { APBD realization }}{\sum \text { APBD budget }}$ & $100 \%$ & $89,13 \%$ & $89,13 \%$ & VS \\
\hline 4 & $\begin{array}{l}\text { Percentage of OPD that } \\
\text { carries out an orderly } \\
\text { administration of financial } \\
\text { administration }\end{array}$ & $\begin{array}{l}\begin{array}{l}\sum \text { OPD which carries out the } \\
\text { administration in an orderly } \\
\text { manner }\end{array} \\
\sum \text { OPD }\end{array}$ & $100 \%$ & $100 \%$ & $100 \%$ & VS \\
\hline 5 & $\begin{array}{l}\text { Percentage of legalization } \\
\text { of regional asset ownership }\end{array}$ & $\frac{\sum \text { land that has been legalized }}{\sum \text { existing land assets }}$ & $56,98 \%$ & $57,89 \%$ & $101,59 \%$ & VS \\
\hline 6 & $\begin{array}{l}\text { Percentage of asset } \\
\text { utilization }\end{array}$ & $\frac{\sum \text { assets utilized }}{\sum \text { assets }}$ & $99,43 \%$ & $53,25 \%$ & $53,55 \%$ & NS \\
\hline \multicolumn{5}{|c|}{ Average Performance Results } & $90,71 \%$ & VS \\
\hline
\end{tabular}


International Journal of Engineering Research and Technology. ISSN 0974-3154, Volume 13, Number 8 (2020), pp. 2030-2038

(C) International Research Publication House. https://dx.doi.org/10.37624/IJERT/13.8.2020.2030-2038

From table 1. it can be explained that there are 2 indicators known that their performance is not reaching the target or is low. Not achieving this performance target is not an indicator that employees are performing poorly, but there could be a cause for other factors. The explanation on the background and theories that support the formulation in this study is how to improve the performance of employees in the BPKAD environment Bondowoso district. While the purpose of this study is to analyze and test the impact of leadership style, work environment and job satisfaction on employee performance in BPKAD Bondowoso Regency.

\section{THEORETICAL FRAMEWORK AND HYPOTHESES}

Performance is a result of work achieved by a person in carrying out the tasks assigned to him based on skill, experience, and sincerity and time (Hasibuan, 2013). One factor that can improve performance is one's leadership style. Leadership style is a person's behavior in managing their organization in achieving company goals (Azhad et al., 2015). Research on the relationship between leadership style and performance has been widely carried out. Research (Qomariah, 2012) states that leadership and organizational commitment do not affect lecturer performance. Research (Wardani et al., 2017) states there is a positive influence between leadership on employee performance. Research Penelitian (Hendrawan \& Budiartha, 2018) shows that the transformational leadership style has a positive and significant effect on auditor performance. Research (Sya'roni et al., 2018) states that the principal's leadership has a positive influence on teacher performance, which means that if the principal's leadership is getting better, it will improve teacher performance. Research (Bentar et al., 2017) states that from the results of multiple linear regression analysis it is known that leadership has a positive and significant effect on performance by 0.458 , meaning that leadership attitudes and styles have a strong influence on organizational life, especially employee performance. Research (Yulianti \& Wuryanti, 2015) produced transformational leadership which had a positive and significant effect on HR performance in BKPPD and BPMP in Konawe Selatan Regency, Southeast Sulawesi Province. Some studies that also examine the relationship between leadership and employee performance include: (Andriani et al., 2018), (Ayuningtyas \& Whidya Utami, 2019), (Andriani et al., 2018), (Kurniawati \& Tobing, 2019),(Sya'roni et al., 2018), (Jayanti \& Wati, 2014), (Wiranata, 2011), (Dolphina, 2012), (Qomariah, 2019), (Sulistyo, 2009), (Sugiyatmi et al., 2016), (Vidianingtyas \& Putri, 2014), (Ishak et al., 2019), (Kurniawati \& Tobing, 2019), (Ayuningtyas \& Whidya Utami, 2019), (Andriani et al., 2018), (Kurniawati \& Tobing, 2019),(Hadiana $\&$ Maya Sari, 2019). From the explanation of the theory of performance and leadership as well as from research that has been done, the hypotheses that can be developed are:

H1: leadership can improve employee performance.

Employee performance can also be influenced by a comfortable work environment. The work environment can be a physical work environment and a non-physical environment. A physical work environment is a place where employees perform daily work activities. While the non-physical work environment is a work environment that includes among others: the relationship between employees and leaders, the relationship between employees and fellow employees, the work atmosphere (Sedarmayati, 2011). The work environment is everything that is around workers and which can affect themselves in carrying out the tasks that are charged, for example, cleanliness, music, lighting, and others (Hasibuan, 2013). Reasearch (Harin, 2014) states that Work motivation, work environment, and organizational culture either partially or simultaneously have a significant and positive impact on the performance of Bank Aceh Syariah employees in Banda Aceh City. Reasearch (Bentar et al., 2017) states that work environment work environment has a positive and significant effect on employee performance Taman Botani Sukorambi Jember. Reasearch (Susanti, 2017) states that the independent variable of work environment and job satisfaction with the dependent variable of employee productivity at RSUP Haji Adam Malik Medan. Research (Feel et al., 2018) indicate that the labor discipline, organizational culture and working environment simultaneously significant effect on the performance of employees at the Village Office Sekarputih, District Tegalampel, Bondowoso. Reasearch (Suwondo \& Sutanto, 2015) indicates that work environment and work discipline has effect to employee performance of bank's employees in Malang city. Research (Firdaus et al., 2017) states that the environment has a significant impact on employee performance South PT.Tanjung Jaya Makmur South Kalimantan. Research (Husnah et al., 2018), states that the job environment has significant effect on employee performence of Royal Hotel Jember. Research (Makkira et al., 2016), states that work environment has positive and significant influence on employees performance at PT. Trans Retail Indonesia (Carrefour) Branch of Panakkukang Makassar. Research (Komaling et al., 2016), states that the recruitment, motivation, and the work environment has a positive and significant in simultaneously and partially on the employee performance PT. Bank Rakyat Indonesia Manado Branch. Research (Abdi \& Wahid, 2017), the work environment has a positive and significant effect on employee performance at the Selayar Islands District Health Office. Research (Priyono et al., 2018), states that the variables of leadership style, teacher motivation and physical work environment, all have a positive effect on teacher performance SMAN 1 Tanggul Jember. Research (Adha et al., 2019), showed that the work environment and work culture has a positive and significant effect on employee performance Jember Regency Social Service. From previous theoretical studies and research. Some studies that also examine the relationship between work environment and employee performance include: (Kurniawati \& Tobing, 2019), (Makkira et al., 2016), (Adha et al., 2019),. The second hypothesis (H2) in this study is:

H2: A Comfortable Work Environment That Can Improve Employee Performance

Employee performance can also improve if employees who work in an organization feel satisfied at work. Job satisfaction as a positive feeling about one's work is the result of evaluating its characteristics. job satisfaction is a general attitude of an individual towards his job. Work requires interaction with coworkers and superiors, follows organizational rules and 
policies, meets performance standards, lives in working conditions that are often less than ideal, and other similar things. Satisfied employees tend to talk positively about their organization, help others or coworkers and try to do more than expected in their work (Robbins, 2011). Job satisfaction is an emotional attitude that is fun and loves work. This attitude is reflected by work morale, discipline, and work performance. Job satisfaction is enjoyed at work, outside of work, and a combination of the two (Hasibuan, 2013). Job satisfaction is a set of employees' feelings about whether or not an employee's job is fun (Davis \& Newstorm, 2008). Job satisfaction is a pleasant and unpleasant emotional state with which employees view their work. Job satisfaction is an individual thing. Each individual will have a different level of satisfaction by the system of values that apply to him. This is due to differences in each individual. The more aspects of the job that fit the individual's desires, the higher the level of satisfaction felt and if employee job satisfaction is considered, the employee will work to the extent of his ability to get what is expected in the work. If the company pays attention to employee job satisfaction, then employees will work harder so that employee work productivity will be higher too (Nawawi, 2008). Research on the relationship between job satisfaction and employee performance has been done a lot.

Research (Pujiarti, 2019), states that partially the job satisfaction factor has an effect of R2 (R Square) of 0.326 (0.571) 2, a relatively weak relationship of $32.6 \%$ occurs on PT. Pilar Guna Usahatama. Research (Koesmono, 2005), states that the direct effet job satisfaction toward job performance is 0.003 on In the Medium Scale Timber Processing Industry Sub Sector in East Java. Research (Susanti, 2017), states that job satisfaction has effect to employee productivity On Haji Adam Malik Hospital Medan. Research (Kurniawan et al., 2019) showed employee job satisfaction has a significant effect on employee performance of PTPN XII Kebun Glantang. Research (Engko, 2008), states that from this study are the positive effect of job satisfaction on job performance. Research (Indrawati, 2013), states that job satisfaction have significant positive impact on employee performance In Private Hospitals In Denpasar City. Research (Changgriawan, 2017), showed that job satisfaction affects employee performance in One Way Production. Research (Saputra et al., 2016), showed that a positive effect job satisfaction of the employee's performance at PT Sun Star Motor Negara. Some studies that also examine the relationship between leadership and employee performance include: (Sadariah, 2019), (Saleh et al., 2016), (Kharisma et al., 2019), (Arda, 2017), (Saputra et al., 2016), (Pujiarti, 2019). Based on the theory and previous research that has been done, the hypothesis that can be built $(\mathrm{H} 3)$ is :

H3: If The Employee Feels Satisfied Working In An Organization, The Employee's Performance Will Increase

\section{RESEARCH METHOD}

This research uses a quantitative approach, quantitative research is a study that basically uses the deductive-inductive approach. This approach departs from a theoretical framework, the ideas of experts, and understanding of researchers based on their experience, then developed into problems and solutions proposed to obtain justification or rejection in the form of field empirical data documents (Sudana \& Setyanto, 2018). The independent variables in this study are leadership style, work environment and job satisfaction. While the dependent variable is employee performance. The independent variable is a variable that affects the dependent variable (Sugiyono, 2013). The population in this study were all employees of the Financial and Asset Management Agency of Bondowoso Regency, totaling 61 civil servant employees. The sampling technique used in this study is saturated or census sampling. Saturated or census sampling is a sampling technique when all members of a population are used as a sample (Gozali \& Nurchayati A, 2015). Thus the number of samples in this study were 61 people.

Validity and reliability tests are used to test the measuring instruments used in this study. Partial Least Square (PLS) is the least squares method used to analyze the effect of independent variables on the dependent variable. The calculation process is carried out by iteration, if the convergent conditions have been reached then the iteration will stop. Hypothesis testing is done with an explanatory research approach. This method is a method approach that uses PLS. This is because in this method there is hypothesis testing. Testing the hypothesis can be seen from the t-statistic value and the probability value. For testing hypotheses using statistical values, for alpha 5\% the t-statistic value used was 1.96. So the hypothesis of acceptance / rejection criteria is $\mathrm{Ha}$ is accepted and $\mathrm{HO}$ is rejected when t-statistics> 1.96. To reject / accept the hypothesis using probability, Ha is accepted if the value of $\mathrm{p}<0.05$.

\section{DATA ANALYSIS AND DISCUSSION}

\section{Descriptive Statistical Analysis}

Based on the respondent's gender the data obtained is the number of male employees more than $51, \%$ of male employees (31 male) and 49\% female employees (30 female employees). Based on respondents by age, it was found that the characteristics of respondents based on age, employees with an age range of 26-35 years were 9 people or $15 \%$, age range 3645 years with the number of employees as many as 34 people or $56 \%$, age range $46-55$ years with the number of employees is 14 people or $23 \%$, and the age is more than 55 years with the number of employees as many as 4 people or $6 \%$. This shows that the majority of BPKAD employees are dominated by productive age groups who should still have high motivation to work. Based on the education of the respondents, it was obtained that the number of BPKAD employees according to the highest education level was from 29 people (48\%), 7 people (11\%) from S2, 7 people (11\%) with DIII education while the second highest number was employees with high school education of 18 people (30\%). This shows that in general it is in accordance with the existing class position, where for stafflevel employees have functioned as programmers, analysts, managers and administrators according to their respective fields. Based on the respondent's tenure, it is known that employees with tenure above 10 years are 36 people (59\%), 610 years of service are 21 people $(34 \%)$ and less than 6 years of service are 4 people (7\%). 
International Journal of Engineering Research and Technology. ISSN 0974-3154, Volume 13, Number 8 (2020), pp. 2030-2038

(C) International Research Publication House. https://dx.doi.org/10.37624/IJERT/13.8.2020.2030-2038

Test Results For Validity And Reliability

Table 2: Test Validity with Combined Loadings and Cross-Loadings

\begin{tabular}{|c|c|c|c|c|c|c|c|c|}
\hline & X1 & $\mathrm{X} 2$ & $\mathbf{Z}$ & $\mathbf{Y}$ & Type (a & SE & P-value & Information \\
\hline $\mathrm{X} 1.1$ & 0.572 & 0.086 & -0.249 & 0.032 & Reflect & 0.096 & $<0.001$ & Valid \\
\hline $\mathrm{X} 1.2$ & 0.572 & -0.108 & 0.279 & -0.368 & Reflect & 0.096 & $<0.001$ & Valid \\
\hline $\mathrm{X} 1.3$ & 0.569 & -0.318 & 0.070 & 0.307 & Reflect & 0.096 & $<0.001$ & Valid \\
\hline $\mathrm{X} 1.4$ & 0.524 & 0.256 & -0.243 & -0.113 & Reflect & 0.098 & $<0.001$ & Valid \\
\hline $\mathrm{X} 1.5$ & 0.028 & 0.553 & 0.056 & -0.113 & Reflect & 0.097 & $<0.001$ & Valid \\
\hline $\mathrm{X} 2.1$ & 0.266 & 0.515 & 0.044 & -0.678 & Reflect & 0.099 & $<0.001$ & Valid \\
\hline $\mathrm{X} 2.2$ & -0.551 & 0.514 & 0.101 & 0.357 & Reflect & 0.092 & $<0.001$ & Valid \\
\hline $\mathrm{X} 2.3$ & 0.249 & 0.549 & -0.350 & 0.321 & Reflect & 0.095 & $<0.001$ & Valid \\
\hline $\mathrm{X} 2.4$ & -0.264 & 0.530 & 0.080 & -0.026 & Reflect & 0.098 & $<0.001$ & Valid \\
\hline $\mathrm{X} 2.5$ & 0.215 & 0.065 & 0.537 & -0.045 & Reflect & 0.098 & $<0.001$ & Valid \\
\hline $\mathrm{Z1}$ & -0.261 & -0.367 & 0.510 & -0.217 & Reflect & 0.092 & $<0.001$ & Valid \\
\hline $\mathrm{Z} 2$ & 0.077 & -0.020 & 0.516 & 0.173 & Reflect & 0.093 & $<0.001$ & Valid \\
\hline $\mathrm{Z} 3$ & -0.244 & 0.129 & 0.562 & 0.256 & Reflect & 0.097 & $<0.001$ & Valid \\
\hline $\mathrm{Z4}$ & 0.088 & 0.110 & 0.514 & -0.279 & Reflect & 0.099 & $<0.001$ & Valid \\
\hline $\mathrm{Z5}$ & 0.111 & 0.364 & 0.158 & 0.576 & Reflect & 0.099 & $<0.001$ & Valid \\
\hline $\mathrm{Y} 1$ & 0.159 & -0.262 & 0.086 & 0.511 & Reflect & 0.092 & $<0.001$ & Valid \\
\hline Y2 & 0.086 & 0.123 & -0.336 & 0.576 & Reflect & 0.099 & $<0.001$ & Valid \\
\hline Y3 & -0.289 & -0.165 & -0.201 & 0.550 & Reflect & 0.097 & $<0.001$ & Valid \\
\hline Y4 & -0.137 & -0.264 & 0.173 & 0.512 & Reflect & 0.099 & $<0.001$ & Valid \\
\hline Y5 & 0.572 & 0.086 & -0.249 & 0.032 & Reflect & 0.096 & $<0.001$ & Valid \\
\hline
\end{tabular}

Notes: Loadings are unrotated and cross-loadings are oblique-rotated. SEs and $\mathrm{P}$ values are for loadings. $\mathrm{P}$ values $<0.05$ are desirable for reflective indicators.

Based on the outputs in table 2, it can be seen that the correlation of each construct and indicator variable with a cross loading value above 0.5 and a p-value of less than 0.05 . so it can be concluded that constructs meet the criteria of discriminant validity, where all latent constructs predict their indicators.
The reliability test is used to measure the consistency of the instrument using WarpPLS 6.0 software, indicated by the value of Composite Reliability and Cronbach's Alpha.

Table 3: Reliability Test Results

\begin{tabular}{ccccccc}
\hline Value & \multicolumn{3}{c}{ Variable } & \multicolumn{2}{c}{ Standart } & Information \\
& $\mathbf{X 1}$ & $\mathbf{X 2}$ & $\mathbf{Z}$ & $\mathbf{Y}$ & & Reliable \\
\hline Composite Reliability coefficients & 0.812 & 0.782 & 0.760 & 0.775 & 0,700 & Reliable \\
Cronbach's Alpha coefficients & 0.769 & 0.772 & 0.746 & 0.753 & 0,600 & . \\
\hline
\end{tabular}


Based on table 3, obtained a significant Composite Reliability value of each variable, namely leadership style (0.812), work environment (0.782), job satisfaction (0.760), employee performance (0.775). The value of Cronbach's Alpha also shows significant results, namely leadership style (0.769), work environment (0.772), job satisfaction (0.746), Employee Performance (0.753). All Composite Reliability values show more than 0.70 and Cronbach's Alpha shows more than 0.60 so it can be concluded that each construct has a high reliability.

\section{Hypothesis Test Results}

Hypothesis testing using Partial Least Square with WarpPLS 6.0 software aims to evaluate the structural relationship in the analysis of the path between latent variables namely the variables of leadership style, work environment, employee performance and job satisfaction. Hypothesis testing of the path coefficient between variables by comparing the $\mathrm{p}$-value with alpha (0.05). Research hypotheses can be accepted if the $\mathrm{p}$-value $<0.05$. The amount of p-value is obtained from the output in WarpPLS 6.0. Testing this hypothesis is also intended to prove the truth of the alleged research that is 3 hypotheses.

Table 4: Beta Coefficients

\begin{tabular}{|c|c|}
\hline & Beta Coefficients \\
\hline $\mathrm{X} 1 \rightarrow \mathrm{Y}$ & 0.31 \\
\hline $\mathrm{X} 2 \rightarrow \mathrm{Y}$ & 0.28 \\
\hline $\mathrm{X} 3 \rightarrow \mathrm{Y}$ & 0.34 \\
\hline
\end{tabular}

\section{DISCUSSION}

\section{The Effect of Leadership Style on Employee Performance}

The results showed that the beta coefficient $(\beta)$ of the leadership style variable was 0.31 with a $\rho$-value of $<0.01$. Because the value of $\rho$-value is smaller than 0.05 , H0 is rejected, thus there is a significant influence of leadership style on the performance of BPKAD employees in Bondowoso Regency. Leadership is the ability of individuals to influence, motivate, and make others able to contribute to the effectiveness and success of an organization. Leadership in organizations is a factor that determines the success or failure of an organization in achieving its goals. Leadership is the ability to influence a group to achieve goals. Leadership plays a central role in trying to understand group behavior, because it is the leader who usually gives direction to pursue goals (Robbins, 2011). Leaders who are able to manage their subordinates by giving examples and examples can improve the performance of their employees. This research is in line with research that has been done by several researchers such as: research (Qomariah, 2012) (Hendrawan \& Budiartha, 2018), (Sya'roni et al., 2018), (Bentar et al., 2017), (Yulianti \& Wuryanti, 2015).

\section{Effect Of Work Environment On Employee Performance}

Based on the results of statistical calculations show that the beta value $(\beta)$ is 0.28 with $\rho$-value of 0.01 for the work environment variable. Because the value of $\rho$-value is smaller than 0.05 , h0 is rejected, thus there is a significant influence of the work environment on the employee performance of BPKAD Bondowoso regency employees. Environmental factors do have a very important role because it is the closest thing to the workers themselves, where the environment not only influences workplace morale but often also has a significant influence on the general decline in morale due to employee dissatisfaction in working both materially and non material (Sedarmayati, 2011). Research in line with this research are: Reasearch (Harin, 2014), (Bentar et al., 2017), (Susanti, 2017), (Feel et al., 2018), (Suwondo \& Sutanto, 2015), (Husnah et al., 2018), (Makkira et al., 2016), (Komaling et al., 2016), (Abdi \& Wahid, 2017), (Priyono et al., 2018), (Adha et al., 2019).

\section{Effect of Job Satisfaction on Employee Performance}

Based on the results of testing the variable job satisfaction on employee performance obtained a beta value $(\beta)$ of 0.34 with a $\rho$-value of $<0.01$. Because the value of $\rho$-value is smaller than $0.05, \mathrm{H} 0$ is rejected, thus there is a significant effect of job satisfaction on employee performance. Employees who are satisfied with the work undertaken can improve their performance. Job satisfaction as a positive feeling about one's work is the result of evaluating its characteristics (Hasibuan, 2013). Job satisfaction is a person's feelings towards his job. Feelings of pleasure are usually described by work discipline, completing work completely, all of which can improve performance (Azhad et al., 2015). Research in line with this research include:research (Pujiarti, 2019), (Koesmono, 2005), (Susanti, 2017), (Kurniawan et al., 2019), (Engko, 2008), (Indrawati, 2013), (Changgriawan, 2017), (Saputra et al., 2016).

\section{CONCLUSION, IMPLICATION, SUGGESTION, AND LIMITATIONS}

Leadership style has a significant effect on employee performance. A good leader is a leader who can improve the performance of his employees. Therefore the leadership style favored by employees must be maintained well. This research of this study do not support the research (Qomariah, 2012) which states that leadership and organizational commitment do not affect lecturer performance. Research of (Wardani et al., 2017) support this research that states there is a positive influence between leadership on employee performance. This research of this study support the research (Hendrawan \& Budiartha, 2018) which states the transformational leadership style has a positive and significant effect on auditor performance. Research (Sya'roni et al., 2018) support this research which states states that the principal's leadership has a positive influence on teacher performance, which means that if the principal's leadership is getting better, it will improve teacher performance. Research (Bentar et al., 2017) support this research which states leadership has a positive and significant effect on performance. Research (Yulianti \& 
Wuryanti, 2015) support this research which states produced transformational leadership which had a positive and significant effect on HR performance.

The work environment has a significant effect

on employee performance. The work environment is a place where employees carry out activities related to work, therefore the work environment must be made as comfortable as possible so that employees are active in working so that performance can improve. This research support the research (Harin, 2014) which states that work environment has a significant and positive impact on the performance. This research support the research (Bentar et al., 2017) which states that work environment has a positive and significant effect on employee performance. This research support the research (Susanti, 2017) which states that work environment has effect on employee productivity. This research support the research (Feel et al., 2018) which states that working environment has effect on the performance of employees. This research support the research (Suwondo \& Sutanto, 2015) which states that work environment has effect to employee performance. This research support the research (Firdaus et al., 2017) which states that the environment has a significant impact on employee performance. This research support the research (Husnah et al., 2018), which states that the job environment has significant effect on employee performence. This research support the research (Makkira et al., 2016), which states that work environment has positive and significant influence on employees. This research support the research (Komaling et al., 2016), which states that the work environment has a positive and significant in on the employee performance. This research support the research (Abdi \& Wahid, 2017), which states that the work environment has effect on employee performance. This research support the research (Priyono et al., 2018), which states that physical work environment has effect on teacher performance. This research support the research (Adha et al., 2019), which showed that the work environment has effect on employee performance.

Job satisfaction has a significant effect on employee performance. Employees who are satisfied with the work that they do, will carry out their work properly, which in turn can improve their performance. This research support the research (Pujiarti, 2019), which states that the job satisfaction has an effect on job performance. This research support the research (Koesmono, 2005), which states that job satisfaction has an effect on job performance. This research support the research (Susanti, 2017), which states that job satisfaction has effect to employee productivity. This research support the research (Kurniawan et al., 2019) which showed that employee job satisfaction has an effect on employee performance. This research support the research (Engko, 2008), which states that job satisfacton has an effect on job performance. This research support the research (Indrawati, 2013), which states that job satisfaction have impact on employee performance. This research support the research (Changgriawan, 2017), which showed that job satisfaction affects employee performance. This research support the research (Saputra et al., 2016), which showed that job satisfaction has effect on the employee's performance.
The implication of this research shows that BPKAD Bondowoso Regency can improve the performance of its employees by paying attention to the leadership styles that exist within the BPKAD environment, the work environment when employees work carrying out their duties, and job satisfaction felt by the employees at BPKAD. why this is important to do because the three variables are proven to be able to improve the performance of BPKAD employees in Bondowoso Regency.

The Bondowoso Regency Regional Financial and Asset Management Agency needs to pay attention to the employee's work environment that is applied because this factor is a very significant factor affecting the performance of the Bondowoso Regency Financial and Asset Management Agency employee. The Regional Financial Management and Asset Management Agency of Bondowoso Regency needs to pay attention to factors that might affect employee performance.

There are several limitations to this study. Respondents from this study were limited to BPKAD Bonodowoso Regency employees. Further research It is recommended to use respondents throughout the Bondowoso Regency SKPD. This study only uses three independent variables. For the next research, other variables such as work motivation, work culture, and OCB are suggested.

\section{REFERENCES}

Abdi, N., \& Wahid, M. (2017). Pengaruh Kompetensi dan Lingkungan Kerja Terhadap Kinerja Pegawai. Jurnal Manajemen dan Bisnis Indonesia, 5(1), 48-61. https://doi.org/10.31843/jmbi.v5i1.139

Adha, R. N., Qomariah, N., \& Hafidzi, A. H. (2019). Pengaruh Motivasi Kerja, Lingkungan Kerja, Budaya Kerja Terhadap Kinerja Karyawan Dinas Sosial Kabupaten Jember. Jurnal Penelitian IPTEKS, 4(1), 47. https://doi.org/10.32528/ipteks.v4i1.2109

Andriani, S., Kesumawati, N., \& Kristiawan, M. (2018). The influence of the transformational leadership and work motivation on teachers performance. International Journal of Scientific and Technology Research, 7(7), 19-29. https://www.ijstr.org/.../The-Influence-Of-TransformationalLeadhership-And -Commitment-Organization-ImplicationsFor-Performance-Employee-State...

Arda, M. (2017). Pengaruh Kepuasan Kerja Dan Disiplin Kerja Terhadap Kinerja Karyawan Pada Bank Rakyat Indonesia Cabang Putri Hijau Medan. Jurnal Ilmiah Manajemen dan Bisnis, 18(1), 45-60. https://doi.org/10.30596/jimb.v18i1.1097

Ayuningtyas, H. F., \& Whidya Utami, C. (2019). The influence of leadership style of first generation, compensation and job satisfaction against the employee performance in foundation of perkumpulan pengelola pendidikan Sejahtera Surabaya. International Journal of Scientific and Technology Research, 8(7), 565-569.

Azhad, M. N., Anwar, \& Qomariah, N. (2015). Manajemen Sumber Daya Manusia. Cahaya Ilmu.

Bentar, A., Purbangkoro, M., \& Prihartini, D. (2017). 
International Journal of Engineering Research and Technology. ISSN 0974-3154, Volume 13, Number 8 (2020), pp. 2030-2038

(C) International Research Publication House. https://dx.doi.org/10.37624/IJERT/13.8.2020.2030-2038

ANALISIS PENGARUH KEPEMIMPINAN, MOTIVASI, DISIPLIN KERJA DAN LINGKUNGAN KERJA TERHADAP KINERJA KARYAWAN TAMAN BOTANI SUKORAMBI ( TBS ) JEMBER. Jurnal Manajemen dan Bisnis Indonesia, 3(1), 1-17.

Changgriawan, G. S. (2017). Pengaruh Kepuasan Kerja dan Motivasi Kerja Terhadap Kinerja Karyawan One Way Production. Jurnal Agora, 5(3), 1-7. http://publication.petra.ac.id/index.php/manajemenbisnis/article/view/6095/5593

Davis, K., \& Newstorm, J. W. (2008). Perilaku Dalam Organisasi. Erlangga.

Dolphina, E. (2012). Pengaruh Motivasi, Kepemimpinan Dan Budaya Kerja Terhadap Kepuasan Kerja Karyawan Serta Dampaknya Pada Kinerja Perusahaan. Seminar Nasional Teknologi Informasi \& Komunikasi Terapan 2012 (Semantik 2012), 2012(Semantik), 1-7. http://publikasi.dinus.ac.id/index.php/semantik/article/view/22 $0 / 232$

Engko, C. (2008). PENGARUH KEPUASAN KERJA TERHADAP KINERJA INDIVIDUAL DENGAN SELF ESTEEM DAN SELF EFFICACY SEBAGAI VARIABEL INTERVENING. Jurnal Bisnis dan Akuntansi, 10(1), 1-12.

Feel, N. H., Herlambang, T., \& Rozzaid, Y. (2018). Pengaruh Disiplin Kerja, Budaya Organisasi Dan Lingkungan Kerja Terhadap Kinerja Pegawai. Penelitian Ipteks, 3(2), 176-185.

Firdaus, Widyanti, R., \& Khuzaini. (2017). PENGARUH MOTIVASI DAN LINGKUNGAN KERJA TERHADAP KINERJA KARYAWAN. Jurnal Komunikasi, Bisnis, dan Manajemen, 4(1), 86-98.

Gozali, I., \& Nurchayati A. (2015). Penerapan Model Strategi Keunggulan Bersaing Berorentasi Lingkungan Pada Perguruan Tinggi Swasta ( PTS ) Di Kota Semarang. Serat Acitiya, 4(2), 33-45.

Hadiana, R. N., \& Maya Sari, N. Z. (2019). The influence of transformational leadhership and commitment organization implications for performance employee State Civil Apparatus (Asn Bandung Indonesian). International Journal of Scientific and Technology Research, 8(1), 8-13.

Hariandja, E. (2007). Manajemen Sumber Daya Manusia. Grasindo.

Harin, I. (2014). Pengaruh Motivasi kerja, lingkungan kerja, dan budaya organisasi terhadap kinerja karyawan dan dampaknya pada kinerja Bank Aceh Syariah di Kota Banda Aceh. Jurnal Magister Manajemen, V(1), 42-56. https://www.google.com/url?sa=t\&rct=j\&q=\&esrc=s\&source $=$ web $\& c d=1 \& c a d=r j a \& u a c t=8 \& v e d=2 a h U K E w i H n M r M 7 d v j$ AhWKpI8KHZ8FD2gQFjAAegQIAxAC\&url=http\%3A\%2F $\% 2$ Fjournal.umy.ac.id\%2Findex.php $\% 2$ Fbti\%2Farticle $\% 2$ Fdo wnload\%2F2451\%2F2431\&usg=AOvVaw2eWz9IL0SzjcSK DquKhp8z

Hasibuan, M. S. P. (2013). Manajemen Sumber Daya Manusia. PT. Bumi Aksara.

Hendrawan, P. R., \& Budiartha, I. K. (2018). Pengaruh
Integritas, Independensi, dan Gaya Kepemimpinan Transformasional pada Kinerja Auditor Inspektorat Kota Denpasar. E-Jurnal Akuntansi, 24, 1359. https://doi.org/10.24843/eja.2018.v24.i02.p20

Husnah, L., Setyowati, T., \& S, W. E. (2018). PENGARUH PELATIHAN KERJA, LINGKUNGAN KERJA DAN KOMITMEN ORGANISASI TERHADAP KINERJA KARYAWAN DI ROYAL HOTEL JEMBER. JURNAL MANAJEMEN DAN BISNIS INDONESIA, 4(1), 33-45. https://doi.org/10.32528/jmbi.v4i1.1714

Indrawati, A. D. (2013). DAN KEPUASAN PELANGGAN PADA RUMAH SAKIT SWASTA. Jurnal Manajemen, Strategi Bisnis, dan Kewirausahaan, 7(2), 135-142.

Ishak, M. N., Mei, T. S., \& Majid, A. H. A. (2019). An effect of authentic leadership as moderator in teachers' performance appraisal satisfaction. International Journal of Scientific and Technology Research, 8(12), 1993-1996.

Jayanti, K. T., \& Wati, L. N. (2014). Pengaruh Gaya Kepemimpinan dan Loyalitas Karyawan Terhadap Kinerja Karyawan. Jurnal Ekobis, 9(1), 71-88. http://ejournal.stiemj.ac.id/index.php/ekobis/article/view/51/3 2

Kharisma, M., Prasilowati, S. L., \& Ayuningtyas, E. A. (2019). Pengaruh Budaya Organisasi Dan Kepuasan Kerja Terhadap Kinerja Karyawan Dengan Komitmen Organisasi Sebagai Variabel Intervening. Jurnal Pengembangan Wiraswasta, 21(2), 135. https://doi.org/10.33370/jpw.v21i2.342

Koesmono, H. T. (2005). Pengaruh Budaya Organisasi Terhadap Motivasi Dan Kepuasan Kerja Serta Kinerja Karyawan Pada Sub Sektor Industri Pengolahan Kayu Skala Menengah Di Jawa Timur. JURNAL MANAJEMEN \& KEWIRAUSAHAAN, 7(2), 162-179.

Komaling, H. J., Adolfina, \& Untu, V. (2016). The Influences Of Recruitment, Motivation, And Work Environment To The Employee Performance Of PT . Bank Rakyat. Jurnal Berkala Ilmiah Efisiensi, 16(01), 738-749.

Kurniawan, R. A., Qomariah, N., \& Winahyu, P. (2019). Dampak Organizationlal Citizenship Behavior, Motivasi. Jurnal Penelitian IPTEKS, 4(2), 148-160.

Kurniawati, D., \& Tobing, D. L. S. (2019). The effect of motivation, working environment, and self leadership on lecturer performance at politeknik negeri jember. International Journal of Scientific and Technology Research, 8(7), 820-825.

Makkira, Gunawan, \& Munir, A. razak. (2016). Pengaruh Disiplin Kerja, Komitmen Organisasi dan Lingkungan Kerja terhadap Kinerja Karyawan pada PT Trans Retail Indonesia (Carrefour) Cabang Panakkukang Makassar. Jurnal Mirai Management, 1(1), 211-227. https://journal.stieamkop.ac.id/index.php/mirai/article/downlo $\mathrm{ad} / 15 / 15$

Mu'ah, M. (2002). Manajemen Sumber Daya Manusia. Grasindo.

Nawawi, H. H. (2008). Manajemen Sumber Daya Manusia,. Gadjah Mada University Press. 
International Journal of Engineering Research and Technology. ISSN 0974-3154, Volume 13, Number 8 (2020), pp. 2030-2038

(C) International Research Publication House. https://dx.doi.org/10.37624/IJERT/13.8.2020.2030-2038

Priyono, B. H., Qomariah, N., \& Pawestri Winahyu. (2018). PENGARUH GAYA KEPEMIMPINAN, MOTIVASI GURU DAN LINGKUNGAN KERJA FISIK TERHADAP KINERJA GURU SMAN 1 TANGGUL JEMBER. Jurnal Manajemen dan Bisnis Indonesia, 4(2), 144-160.

Pujiarti. (2019). Pengaruh Kompetensi Dan Kompensasi Terhadap Kinerja Karyawan Dengan Kepuasan Kerja Sebagai Variabel Intervening Pada PT . Pilar Guna Usahatama. PRIMANOMICS : JURNAL EKONOMI DAN BISNIS -, 1, 114.

Qomariah, N. (2012). Pengaruh Budaya Organisasi, Kepemimpinan dan Komitmen Organisasi Terhadap Kinerja Dosen. CBAM-FE-Unissula.

Qomariah, N. (2019). Pengaruh Budaya Organisasi, Kepemimpinan Dan Komitmen Organisasi Terhadap Kinerja Dosen Pada Perguruan Tinggi Swasta Di Kabupaten Jember. Conference In Business, Accounting, And Management (CBAM), 1(3), 787-801. http://jurnal.unissula.ac.id/index.php/cbam/article/view/172

Robbins, S. (2011). Perilaku Organisasi. Salemba Empat.

Sadariah. (2019). Influence of style leadership to satisfaction work and employee performance at a company's cargo Hasanuddin International Airport Makassar. International Journal of Scientific and Technology Research, 8(1), 37-41.

Saleh, A., Ramly, M., Gani, M. U., \& Suriyanti, S. (2016). Factors Affecting The Job Satisfaction And Performance Of Nurses Private Hospitals Class B In Makassar. International Journal of Scientific and Technology Research, 5(10), 74-77.

Samsudin, S. (2006). Manajemen Sumber Daya Manusia. Pustaka Setia.

Saputra, A. T., Bagia1, I. W., \& Yulianthini, N. N. (2016). Pengaruh Kepuasan Kerja dan Loyalitas Karyawan Terhadap Kinerja Karyawan. Jurnal Manajemen Indonesia, 4(1), 1-8. http://publication.petra.ac.id/index.php/manajemen-

bisnis/article/view/6095/5593

Sedarmayati. (2011). Manajemen Sumber Daya Manusia, reformasi birokrasi dan manajemen pegawai negeri sipil. PT. Refika Aditama.

Sudana, I. M., \& Setyanto, R. H. (2018). Metode Penelitian Bisnis dan Analisis Data Dengan SPSS. Penerbit Erlangga.

Sugiyatmi, Minarsih, M. M., \& Edward Gagah. (2016). Pengaruh Motivasi, Gaya Kepemimpin Dan Lingkungan Kerja Terhadap Disiplin Kerja Serta Dampaknya Terhadap Kinerja Karyawan Di Pt Bina San Prima. Journal Of Management, 2(2).

http://jurnal.unpand.ac.id/index.php/MS/article/view/534/520

Sugiyono. (2013). Metode Penelitian Pendidikan Pendekatan Kuantitatif, Kualitatif, dan R\&D. Alfabeta.

Sulistyo, H. (2009). Analisis Kepemimpinan Spiritual Dan Komunikasi Organisasional Terhadap Kinerja Karyawan. Ekobis, 10(2), 11.

Susanti, N. (2017). EFFECT OF ENVIRONMENTAL WORK AND WORK SATISFACTION OF EMPLOYEE
PRODUCTIVITY Sekolah Tinggi Agama Islam ( STAI) Yaptip Pasaman Barat Email: susantinovi57@gmail.com PENDAHULUAN Rumah sakit merupakan tatanan pemberi jasa layanan kesehatan memiliki peran ya. 3(2), 137-154.

Suwondo, D. I., \& Sutanto, E. M. (2015). HUBUNGAN LINGKUNGAN KERJA, DISIPLIN KERJA, DAN KINERJA KARYAWAN. Jurnal Manajemen dan Kewirausahaan, 17(2), 41-59. https://doi.org/10.9744/jmk.17.2.135

Sya'roni, Herlambang, T., \& Cahyono, D. (2018). DAMPAK MOTIVASI, DISIPLIN KERJA DAN KEPEMIMPINAN KEPALA SEKOLAH TERHADAP KINERJA GURU. Jurnal Sains Manajemen \& Bisnis Indonesia, 8(2), 131-147.

Vidianingtyas, R. N., \& Putri, W. H. (2014). Pengaruh kompensasi, kepuasan kerja, motivasi kerja dan gaya kepemimpinan terhadap kinerja karyawan pada perusahaan jasa katering di daerah istimewa yogyakarta. Efektif Jurnal Bisnis dan Ekonomi, 5(1), 99-110.

Wardani, D. K., Cahyono, D., \& Herlambang, Toni Qomariah, N. (2017). PENGARUH GAYA KEPEMIMPINAN TERHADAP KEPUASAN KERJA DAN KINERJA DENGAN KOMITMEN ORGANISASI SEBAGAI VARIABEL INTERVENING DI RUMAH SAKIT ISLAM LUMAJANG EFFECT. Jurnal Sains Manajemen \& Bisnis Indonesia, 7(2), 208-231.

Wiranata, A. A. (2011). Pengaruh Kepemimpinan Terhadap Kinerja Dan Stres Karyawan (Studi Kasus : Cv. Mertanadi). Jurnal Ilmiah Teknik Sipil, 15(2), 155-160. http://ejournal.stiemj.ac.id/index.php/ekobis/article/view/51/3 2

Yulianti, \& Wuryanti. (2015). PENGARUH KEPEMIPINAN TRANSFORMASIONAL, INTEGRITAS PERILAKU DAN KEPERCAYAAN TERHADAP PIMPINAN DALAM PENINGKATAN KINERJA SDM (StudiBLHKP,. 2 nd CBAM, 38, 282-300. 